\title{
IN SEARCH OF VIABLE BUSINESS MODELS FOR DEVELOPMENT: SUSTAINABLE ENERGY IN DEVELOPING COUNTRIES
}

\author{
Ans Kolk \& Daniel VAN Den BuUSe \\ Corporate Governance: International Journal of Business in Society, forthcoming
}

\begin{abstract}
Purpose - Although the crucial role of business, and of business-based approaches, in development is increasingly emphasised by academics and practitioners, we lack insight into the 'whether and how' of viable business models, in environmental, social and economical terms. This article analyses private-sector involvement in development, including a business perspective of firm-level factors, taking the case of sustainable energy in developing countries.

Design/methodology/approach - In the framework of the international business and development debate, we examine the 'state of the art' on sustainable energy and business involvement, and present our own research on illustrative cases from local companies involved in renewable, off-grid rural electrification. Implications are discussed, viewed from the broader perspective of business models.
\end{abstract}

Findings - Existing studies on sustainable energy take macro-economic and/or policy-oriented approaches, containing specific case studies of rural electrification and/or recommended financing/delivery models. We categorize them on two dimensions (levels of subsidies and public/private involvement) and conclude that market-based models operating without subsidies do hardly exist in theory - and also not in practice, as our study shows that companies can at best have part of their portfolio non-subsidized based on customer segmentation or require socially-oriented investors/funders.

Research limitations/applications - This exploratory study can be a starting point for further indepth analyses.

Practical implications - The article outlines challenges faced by companies/entrepreneurs when aiming for viable business models, and provides insights to policy-makers who want to further the role of business in sustainable (energy) development.

Societal implications - Sustainable energy and development are crucial and interlinked issues highly relevant to global society, as exemplified by the UN year of Sustainable Energy for All and Rio+20.

Originality/value - The article contributes new dimensions and perspectives that have been left unexplored, and that are crucial for reducing poverty and stimulating sustainable (energy) development.

Keywords - access to energy; business models; developing countries; electricity; off-grid; poverty; renewables; rural electrification; sustainable development; sustainable energy

\section{ACKNOWLEDGEMENT}

This article is one of the publications resulting from a longer-term research programme on business and development, and on partnerships. A part of the latter line of research (related to partnerships for sustainable development) has been carried out together with the Partnerships Resource Centre (see Kolk and Pinkse, 2010a, 2010b; Van den Buuse et al., 2012). 


\title{
IN SEARCH OF VIABLE BUSINESS MODELS FOR DEVELOPMENT: SUSTAINABLE ENERGY IN DEVELOPING COUNTRIES
}

\author{
ANs Kolk \& DANIEL VAN DEN BUUSE
}

\section{INTRODUCTION}

In the past decade, international interest in the role of business in furthering development has increased, and from a growing number of perspectives. Be it the policy debate in the framework of the Millennium Development Goals or the literature on bottom of the pyramid, subsistence markets or partnerships, involvement of the private sector has been emphasised. As such, attention for economic, entrepreneurial activity in developing countries, including the impact of foreign investment on development, is not new at all (for overviews see Fortanier and Kolk, 2007; Meyer, 2004). What has changed in more recent years is that multinationals in particular are increasingly called upon to help alleviate poverty (Kolk et al., 2006), and are thus seen as 'part of the solution' - no longer as only 'part of the problem'. In addition, they are not just asked to contribute to economic development 'per se', but also to address social and environmental issues. In this way, business is expected to take on roles and responsibilities that were previously regarded as belonging to the domain of government, and/or of non-governmental organizations (NGOs).

Especially multinationals have become very active in a variety of fields, ranging from mere philanthropy to more strategic corporate social responsibility efforts, sometimes even linked to their core business, as can be seen in some business-NGO partnerships or supplychain activities (Kolk et al., 2008). Since the early 2000s, attention has even shifted to the possibility to make a profit out of poverty-oriented approaches, as put forward by the Bottom/Base of the Pyramid (BOP) thesis as initially launched by Prahalad and Hart in 1999. While there is no evidence for a systematic 'Fortune at the BOP' for multinationals beyond a limited number of high-profile, oft-cited cases - as the poorest of the poor do not have sufficient purchasing power to generate huge market opportunities (e.g. Garrette and Karnani, 2010; Ireland, 2008; Kolk et al., 2010; Pitta et al., 2008) - the BOP idea has put poverty strongly on the international business agenda. Interestingly, the recent emergence of BOP 2.0 (Simanis and Hart, 2008), in which the poor stand much more central, as cocreators of BOP initiatives, has meant a certain convergence with the subsistence market(place)s approach (Viswanathan et al., 2009; Viswanathan and Sridharan, 2009).

In line with that bottom-up, micro-level perspective, the overall debate has moved towards the role of smaller, local companies, and to a broader interest in reconciling the 'social good' with economic objectives, i.e. beyond corporate social responsibility or philanthropy only, and in such a way that it can reach sufficient scale to address the urgent and huge unmet needs of the poor. However, although the crucial role of business, and of business-based approaches, in development is thus frequently underlined by academics and practitioners, we lack insight into the 'whether and how' of viable business models, in environmental, social as well as economical terms. Despite generic calls at the macro level and statements that business can help to alleviate poverty, how this might work from a business perspective that considers firm-specific factors, is not so clear. This article aims to contribute by analysing private-sector involvement in development, taking the case of sustainable energy in developing countries. This is highly relevant as energy is often seen as a crucial lever for development, as the next section will explain in more detail. We also 
examine the 'state of the art' on sustainable energy and business involvement, and subsequently present our own research on illustrative cases from local companies involved in renewable rural electrification. This includes a discussion of implications, viewed from the broader perspective of business models for development as well.

\section{THE CRUCIAL ROLE OF ENERGY IN DEVELOPMENT}

Energy is important for social and economic development, and crucial for individuals and communities in developing countries to meet their basic needs. The essential role of access to clean and reliable sources of energy for realizing sustainable development has been widely recognized, as reflected in the UN's decision to label 2012 as the international year of 'Sustainable Energy for All'. It is estimated that almost one fifth of the world population does not have access to electricity, and this situation is expected to still hold for 1.2 billion people in 2030 (IEA, 2010). Energy is directly linked to increased income and productivity, and indirectly to better health, education, quality of life, and human development in general. Access to energy can act as an incubator of economic activity and have an important impact on long-term poverty reduction, as it can increase livelihood options by allowing households to engage in a more diverse range of income-generating activities and make pre-existing activities more efficient (Biswas et al., 2001; Davis, 1998; Sagar, 2005; Sharma, 2006). Besides domestic use, electricity can improve healthcare: it enables the possibility of providing clean water and lighting, of conserving medicines, vaccines, and blood storage, as well as access to usage of modern medical equipment. In terms of education, learning conditions could be dramatically improved as electricity means lighting during the evening, and facilitates access to internet, and thus to knowledge and information beyond the local community.

Considering that approximately $80 \%$ of the people in developing countries who lack access to electricity live in rural areas beyond the reach of the electricity grid (ARE, 2008), rural electrification is a crucial issue in access to energy. The conventional approach to electrification has been to extend the electricity grid powered by centralized fossil fuelbased power plants operated by the national utility. This is based on the model adopted in developed countries, where national governments had traditionally created such systems. The reality in many developing countries, however, is very different, because it is financially, technologically and organizationally almost impossible to extend the central grid to all remote and rural parts of the country. Grid-connected electricity is often only available in urban areas, because of high costs for connection and subsequent power transmission losses resulting from the large distances that need to be bridged (ARE, 2008). This thus calls for offgrid, decentralized solutions for energy provision, either based on existing technologies such as diesel generators or emerging renewable energy technologies (RETs), which provide access to energy beyond the public electricity grid. A diverse range of such RETs that are relevant for developing countries has emerged over the years (see Box 1). RETs in fact relate to two of the three (interlinked) objectives adopted in the framework of Sustainable Energy for All: i.e. to "ensure universal access to modern energy services" and "double the share of renewable energy in the global energy mix". ${ }^{1}$

$===============$
Box 1 around here
$==============$

While decentralized RET-based electrification offers clear benefits from an environmental and social perspective (e.g. by avoiding emissions from fossil fuels and negative health 
effects from using traditional biomass fuels such as charcoal and wood for cooking and heating inside), achieving economic viability has been problematic. In addition to challenges related to financing and upscaling beyond pilot projects, Mohiuddin (2006) mentions that RETs are not yet widely adopted in developing countries due to a lack of available infrastructure for RETs, which creates high initial capital costs for RET-based electrification projects, and limits the possibilities for a wider, sustained market development. The main challenge is to achieve broad access to affordable, modern energy services in countries that lack them, and to find a mix of energy sources, technologies, policies and behaviours that avoid the negative environmental impact related to fossil fuels (Spalding-Fecher, 2005; Spalding-Fecher et al., 2005).

However, as RETs involve local solutions, frequently for remote communities only, national governments in developing countries might often not (be able to) play an active role in their provision at affordable price levels for poor people. This is one of the reasons that many other (non-)governmental organizations have become engaged in stimulating investments in off-grid solutions in those parts of the world that would be neglected otherwise. Through different kinds of partnerships and financing schemes, such organizations have often tried to attract the interest of the private sector while keeping costs for electricity users low. However, creating the right kind of incentives to step up investments in off-grid energy solutions and designing long-term viable business models to sustain rural electrification has been very difficult for for-profit companies. Academic research including work by Chesbrough et al. (2006) has also shown that many technologies developed with the intention to be implemented in developing countries did not achieve commercial viability, or remained limited to charitable distribution programmes by donor organizations.

In the next section, we pay attention to financing and delivery models in RET-based electrification as they have come to the fore in the literature, and compare the options that have emerged. We subsequently present our own research on some illustrative cases from local companies involved in RET-based electrification in developing countries, which represent a market-based bottom-up approach, and characterise the issues at play. Given that the importance of private sector involvement to establish energy markets in developing countries for long-term sustainability is increasingly recognised, the viability of the underlying business models of these initiatives is considered. We also discuss the implications, viewed from the broader perspective of business models, for both research and practice in sustainable development.

\section{FINANCING AND DELIVERY MODELS FOR RENEWABLE ENERGY TECHNOLOGIES}

While the importance of access to energy for sustainable development in developing countries is widely recognized, the issue has not yet received mainstream attention in the academic business and management literature. Publications have included a range of case studies, covering sub-Saharan Africa (e.g. Jacobson, 2007; Nygaard, 2009; Wamukonya and Davis, 2001), South-East Asia (e.g. Byrne et al., 1998; Ling et al., 2002; Miller and Hope, 1999; Nguyen, 2007; Umree and Harries, 2006), Oceania (e.g. Umree et al., 2008, 2009), and the Indian subcontinent (e.g. Biswas et al., 2001; Chakrabarti and Chakrabarti, 2002; Rao et al., 2009; Sharma, 2007). However, they have focused on concrete (technical) issues, usually taking a more macro-economic and/or policy-oriented approach, including the identification of success factors and the implications for (donor) investment policies in terms of delivery and financing mechanisms. Research that examines private-sector involvement from a 
business perspective, including the factors at the level of the firm that influence the viability of business models for RET-based electrification, has been lacking.

If we consider the existing macro/policy studies, they have predominantly consisted of two types: empirical papers based on case studies on rural electrification in specific (sets of) developing countries using RET as an energy source, and policy-oriented papers looking at the existing policies and financing mechanisms for stimulating investments in RETs and energy-efficiency technologies. Particularly publications in the latter category, which sometimes contain insights on emerging delivery models on how sustainable energy projects are developed and implemented, are potentially interesting for the purpose of this article; that also applies to financing schemes that address funding mechanisms within a project. The models and schemes identified by different authors and multistakeholder organizations such as the Alliance for Rural Electrification (ARE) and Renewable Energy Policy Network for the 21st Century (REN) overlap in multiple ways, and share important characteristics that we will briefly summarize next.

Figure 1 positions the various delivery and financing models as included in four main recent studies, based on two basic dimensions that come to the fore in each decentralized off-grid solution to access to energy in developing countries: the extent to which subsidies are included in the model in question, ranging from fully subsidized to non-subsidized, on the one hand; and the nature of the actors involved, public or private, on the other hand. While this overview is indicative only (with sometimes dotted lines if there is a range and not just one point), it gives insight into the different options distinguished, and shows their variety, as well as similarities. We will not discuss all four studies in detail, but focus on evolution of thinking over the years, in which the desirability of models carried out by private actors without subsidies is the most recent phenomenon in a field that has traditionally relied on donation-based, donor-driven projects.

Figure 1 around here

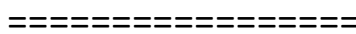

Based on his study on rural electrification using solar technology in Sub-Saharan Africa, Nygaard (2009) identifies delivery models that cover the whole range. At one extreme, there is the traditional philanthropic model (\#1 in Figure 1), a 'donor-driven' approach in which developed countries provide funding to developing countries on a project basis, and government organizations are fully in charge of all aspects related to the RET-based electrification system. This does not provide a basis for establishing a viable market, and large organizations such as the World Bank are trying to move beyond this model (e.g. Martinot, 2001). The other end of the spectrum consists of a commercially-led delivery model (\#2 in Figure 1) based on cash sales, with zero subsidies. This resembles a classic market-based model in which private organizations and/or individuals are end-users of the electricity, own and finance the system and are fully responsible for installation and maintenance - roles all fulfilled by a government organization in the previous model. In between these two, we find a multi-stakeholder model (\#3) in which private entities are still end-user of the electricity and have ownership over the installation, but financing in is provided by a donor, financing institution or dealer through a low to medium-size investment in the overall project. This approach is broad by definition and can involve a variety of different actors, and is relevant as a possible alternative to the two other models mentioned earlier. Based on research in Brazil, Cambodia and China, Zerriffi (2011) suggests comparable models, although his most 'extreme' private model (\# 13 in Figure 1) is one that focuses on decentralization which can cover both established (fossil-based) mini-grids and 
solar systems. While highly interesting for this context, Zerriffi (2011, p. 144) notes that this has "not been around long enough to have significant impact and allow evaluation of sustainability and replicability".

The literature also contains various financing models, as discussed most specifically by Umree and Harris (2006) and ARE (2008), and included in Figure 1 as well. This again ranges from donations/subsidies on the one hand (\# 8 and \#19) and more or less fullly private funding, such as those based on cash sales (\#7), on the other. The latter variant only works for households wit sufficient purchasing power, which excludes the (poorest of the) poor (Jacobson, 2007). In this context, micro-financing is sometimes mentioned as a possibility (\#18). While this instrument in general has not been without criticism, a debate beyond the scope of this article, ${ }^{2}$ several authors adjusted it to the energy context to support both RET supply and demand (Mohiuddin, 2006; O'Brien et al., 2007; Rao et al., 2009). Rao et al. (2009) most specifically proposed an 'energy-microfinance framework' to pool energy expertise and financial management skills. Figure 1 also contains fee-for-service models (\#4, \#5 and \#6), in which a national utility or energy service company owns, finances and maintains the installation, and is responsible for maintenance while periodically charging a fee to households based on usage. An affordability payment scheme or specific subsidy can be part of such an arrangement. ARE (2008) distinguishes several models in which subsidies are integrated, such as a regulated purchase tariff (\#14), with subsidies that complement tariffs paid by consumers, or fund electricity producers either for the number of connections established (\#15) or via power purchase agreements (\#17) that guarantee producers a specific price and a minimum purchase to stimulate investments.

As shown in Figure 1, the number of market-based models that operate without subsidies is fairly limited, despite persistent calls for private investment for more than a decade, particularly by international development organizations such as the World Bank. This has been accompanied by the identification of a range of key demand and supply factors to be addressed by policies for infrastructure, investments, institutions, entrepreneurial and consumer behaviour (Martinot, 2001; Miller and Hope, 2000, World Bank, 2008a, 2008b). However, as noted by Mohiuddin (2006, p. 122), "the majority of support for RETs in developing countries still comes from local and state governments or from foreign donors, which is not sustainable because government funds fluctuate as priorities shift and as national and regional crises spring up from time to time and aid flows from foreign donors can ebb at times". A 2012 UN document on Sustainable Energy for All urges all stakeholders to take steps, and suggests many possibilities for action. It mentions, "by way of illustration" that "private sector stakeholders could commit to", inter alia, "develop and deploy business models that deliver and build value from sustainable energy solutions" (UN, 2012, p. 14).

Interesting is the unequivocal statement in that same "Framework for Action" (UN, 2012, p. 19) that "In many off-grid situations, small-scale sustainable energy solutions for productive uses of energy are not only affordable under the right business models, but cheaper than current sources of energy. This creates opportunities for local business development consistent with all the objectives of Sustainable Energy for All. There are numerous recent success stories involving innovation in energy access by small-scale businesses and CSOs [civil society organizations]. Replicating and scaling up successful community-based delivery models could have a significant impact, both as stand-alone efforts and as part of national efforts described in the previous example". These national activities comprise joint activities funded by the private, public and non-profit sectors. The emphasis on collaboration also comes to the fore in the quotation "Private sector 
stakeholders can make a significant contribution toward achieving the Sustainable Energy for All objectives, both on their own and - more importantly - through partnerships" (UN, 2012, p. 14).

It is not clear whether the terms 'affordability', 'cheaper' and 'success stories', as cited above, refer only to reaching poor populations or also to the economic viability for business. The request to companies, cited above, to make a commitment to develop business models suggests that the focus is more on access to energy and the impact for developing countries. While understandable, this still leaves open the question how and to what extent RET business models can become viable and thus sustainable in both economic and social/environmental terms. To shed some light on these aspects, we examined four illustrative cases of bottom-up business initiatives of local companies. Below first the methodology and approach will be explained, followed by a presentation of findings, embedded in a broader discussion of business models.

\section{METHODOLOGY}

\section{Sample and method}

We analyzed four local companies that have developed innovative business models for providing RET-based off-grid energy solutions to households and villages living beyond the reach of the electricity grid. These are illustrative cases originating from four countries in Asia: Kamworks (Cambodia), Sunlabob (Laos), Husk Power Systems (India) and Grameen Shakti (Bangladesh). We selected these companies after a web-based search for examples of entrepreneurial, local activity in RET-based rural electrification in developing countries as they show different aspects and technologies used in developing countries, and positioned themselves as market-oriented organizations. Other examples could have been taken, for example in Africa, although the number of for-profit ventures seems to be smaller in reality than it looks at first sight as many appear private but turn out to be non-governmental or hybrid at best. The number of local companies active in RETs appears to be rather limited, at least when doing a selection via internet sources.

Primary and secondary data was collected from public sources, particularly websites and reports, supplemented with nine semi-structured interviews with experts in the field, held by the second author in the first half of 2011, to gain insight into emerging RET business models in developing countries. Interviewees were three directors of small local companies (including two of the Asian companies included in this study and one active in Africa), four senior staff members of international governmental and non-governmental (development) organizations, and two other experts in the field of energy in developing countries. Based on insights from the literature, questions focused on main challenges of RETs for access to energy, the role of the private sector and the emergence of market-based business models, and the (possible) role of collaboration with partners from the public, private and/or nonprofit sectors in this regard.

Of the four companies, Grameen Shakti is somewhat exceptional in view of its explicit positioning as a not-for-profit company. Furthermore, it is part of the broader Grameen family of organizations which contains an umbrella of non-profit and for-profit ventures, all related to the initial Grameen Bank set up to provide micro-credit. At the same time, it is a relatively large renewable energy company that has focused on offering RETs in rural areas for many years already and therefore interesting to consider as well. In addition, like the other three (Husk Power Systems, Kamwork and Sunlabob), it operates according to 
a market-oriented approach, and can thus be found in the lower half of Figure 1 as presented in the previous section. Issues related to levels of subsidization will be discussed in the next section when we explore their respective business models, in the context of the literature on this topic.

\section{Business model perspectives}

In the past few years, business models have received growing attention in the management literature, ${ }^{3}$ but the number of articles that reckons with the situation in developing countries has been very limited, except for a few that focus on business-NGO collaboration in this context (Chesbrough et al., 2006; Dahan et al., 2010) or on opportunities for (Western) multinationals in emerging markets (e.g. Eyring et al., 2011). Yunus et al. (2010) describe first-hand experiences with a few Grameen companies from a 'social business model' perspective, but this is less linked to the generic literature on the topic and several details (for example on funding and profitability) are far from clear. We therefore searched for additional, older publications as well for frameworks that might be helpful to discuss the type of companies, issues and locations covered in this study, which also included Morris et al. (2005) and Shafer et al. (2005).

Eyring et al. (2011) turned out to be less applicable in view of its starting point of competition on either differentiation or price. Given the early stage of the market for RETs with commercial viability still being explored and companies emerging only recently, the model appears not so relevant for the purpose. Its components (customer value proposition, key resources and processes, and profit/cost structure) bear resemblance to other models though, such as Shafer et al. (2005). The framework of Shafer et al. (2005, p. 202) consists of strategic choices, value creation, value network and value capture, with several subcategories, following from their definition of a business model as "a representation of a firm's underlying core logic and strategic choices for creating and capturing value within a value network". However, the elements are too specific given the nascent state of the market and the companies, the limited information available for the local companies and their lack of formalization compared to large (Western) companies.

The most appropriate model for the purpose of this article appears to be Morris et al.'s (2005) more open set of questions at the foundation level as summarized in Table 1, coupled with a proprietary level that considers the unique innovation of the specific venture. We will discuss these aspects in more detail below, using the findings of our research on the four companies.

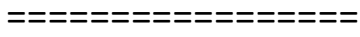

Table 1 around here

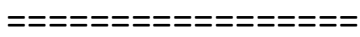

\section{EMERGING RET BUSINESS MODELS}

Table 2 contains some key characteristics of Grameen Shakti (GS), Husk Power Systems (HPS), Kamworks and Sunlabob, particularly location, main products/services and customers, relationships, and key achievements as presented by the companies themselves and as honoured by external parties via awards. It also includes references to the most applicable delivery/financing models as discussed earlier in this article (see Figure 1). The Table gives fairly detailed information regarding the activities of the companies, also in terms of technologies (cf. Box 1) and the specific organizations with which they partner. In our 
discussion below we will not pay much attention to the technicalities but rather aim to generate insight into broader implications for sustainable energy and development considering the (im)possibilities of market-based, private-sector involvement. Components of Table 1 will be used to characterize the (unique) features of the companies, as well as the sector more generally. The first subsection addresses the first four questions of Table 1 as well as the proprietary level, followed by the last two questions to explore the economic viability and (future) investment models.

Table 2 around here

ニニニニニニニニニニニニニニニニニ

\section{Offerings, markets, positioning and capabilities}

Overall, local companies in off-grid rural electrification offer a portfolio of energy 'solutions', generally consisting of different renewable-energy technologies to various customers: business-to-business and/or business-to-consumer, in a range from individual-level to village-level products and services. End-consumers vary in their ability to pay as many are poor which means that there is often financial support via donor organizations, in which case these organizations can be argued to resemble, in a sense, a 'business' customer (as endconsumers are beneficiaries). Business-to-business activities are commercial if they cater to the needs of local companies. It is possible to buy RET-products as a single item, but also in combination with other products and/or services such as installation, maintenance, training, project management, and sometimes financing and rental schemes. The local companies usually do not manufacture RET-products but focus on value-added reselling of standardized solutions that are customized and locally-adapted where needed so as to ensure a reliable electricity supply. This is a challenge as it requires a network of maintenance and repair as well as stable quality products all delivered in distant rural areas. RET-applications are currently still niche markets, but with a potential to become much larger in view of the large number of people in developing countries without access to energy.

Within this overall sector framework, the four local companies also exhibit some differences in terms of size, product-service solutions and customers, as Table 2 shows. All four are locally-focused in their respective home countries; only Sunlabob has started some activities on a project basis in other countries as an outflow of their international recognition and contacts. Husk Power Systems is unique for its cost-effective electricity generation through a biomass gasifier running on discarded rice husk, abundantly available in rural India, which is subsequently distributed through a village grid. This is a specific business model and technology developed by HPS aligned to local conditions. The other three companies have a broader RET-portfolio, with Grameen Shakti standing out for its much larger size. Peculiar to GS is that its RET-based solutions come with a micro-financing 'soft credit' scheme developed in collaboration with the Grameen Bank. The company is locally embedded in Bangladesh through more than 1200 branch offices, which provides a clear infrastructure.

Although based in two different countries, Kamworks and Sunlabob are rather similar in many respects, considering their main products/services, types of consumers and the fact that they are run by an entrepreneur strongly embedded in the local/regional context. One dissimilarity is Kamworks' primary orientation at solar energy, which means that it is more focused in the type of renewable energy than Sunlabob. Different from GS and HPS, which predominantly cater to low-income (end) consumers only, Kamworks and Sunlabob serve a 
broader mix of customers, including local business on a fully commercial basis as well as endconsumers, villages and/or individuals, who pay themselves or are (partly) funded via international donor projects. This relates directly to the economic factors and types of investment models of the local companies.

\section{Economic viability and (future) models}

Although it proved impossible to obtain hard revenue and profit data from the companies, our research confirms that building a viable business model in this sector in the present situation is rather difficult. While circumstances differ and so do the companies we studied, subsistence appears to be the key current focus, even though the aim is to move towards a stable income and subsequently growth model. Particularly Husk Power Systems has an innovative and relatively simple approach, but this requires the abundant availability of husk material. Even in such unique conditions, however, financing for pilots and start-up costs are required. This is all the more the case for other locations, where only other RETs can be used and where rural electrification is not viable on its own as upfront costs for installation, infrastructure and material as well as operating and service-network costs are difficult to fund. In the absence of sufficient collateral, banks and investors are generally not willing to provide loans (at affordable interest rates) to companies in view of long payback periods and problems with cost recovery in general. End-consumers face the same type of problems, in a context where poverty reigns and even micro-credit tariffs are too high.

The four companies that we studied are set up and function as private entities, and strongly advocate market-oriented approaches and entrepreneurship. At the same time, they generally have a variety of (non-)governmental partners with which they collaborate. Often these serve to gain, for example, access to subsidies or other types of support from international organizations to service the real poor and/or start up a business in renewable off-grid energy. There are differences in the degree to which the local companies rely on such external sources. Kamworks and Sunlabob have a mixture of self-sustaining commercial activities alongside subsidized projects based on donor funding. The latter type is focused at reaching the poorest consumers while commercial activities target business markets or middle-class consumers. GS explicitly mentions to get "no direct subsidies" but, interestingly, the company does not aim for profit, perhaps because it is part of the broader Grameen family of organizations, which has the provision of micro-credit as cornerstone of the overall business model. So indirect support may be obtained this way or otherwise, but information about this could not be found. HPS has designed an innovative for-profit model based on specific local circumstances which has potential to be scaled up. Still, the company has several socially-oriented investors, including the Shell Foundation.

The variety shows that several models may be needed to address local demands, adjusted to the specific context. The emergence of market-based approaches generally does not diminish the role of other (non-)governmental actors as the challenges of 'sustainable energy for all' are tremendous. In the final section, we will draw conclusions and discuss the implications for the role of business in sustainable development.

\section{DISCUSSION AND CONCLUSIONS}

While renewable, off-grid electrification in developing countries offers clear benefits in environmental and social terms, and is needed in view of the international objective to realise 'Sustainable Energy for All', the economic viability has been a real issue. As a clear 
illustration of the complexities related to large-scale involvement of business in furthering development, this article examined sustainable energy, and explored how innovative market-based models for RET-based rural electrification are emerging as part of a move away from more traditional, purely donor-funded projects. In line with the importance of the private sector-based solutions in establishing access to energy in developing countries, as emphasized by academics and practitioners, the cases of Sunlabob, Husk Power Systems, Kamworks and Grameen Shakti provided more insight in various business models in rural electrification. They also show the organizational, financial, regulatory, and technological challenges, and raise questions as to possible roles that remain or (re-)emerge for governmental and non-governmental actors.

In comparing these local-level market-based models to international-level donordriven approaches, a major strength of the former is the companies' adaptability to local conditions as opposed to more generic one-size-fits-all electrification solutions. As these companies are, almost by nature, embedded in local communities and possess in-depth knowledge of the distinct characteristics of markets and consumers, they seem better able to develop context-specific solutions which also creates legitimacy for their approach. Kamworks in Cambodia and Sunlabob in Laos follow a mixed model with segmentation based on income levels and energy needs, thereby providing the appropriate technological solution that suits consumers best. Taking Kamworks as an example, the company emphasizes its commitment to introducing an energy ladder based on this need-and income-segmentation, whereby the lowest-income households have the opportunity to purchase a Moonlight solar-powered lantern (through a rental scheme, which reduces the upfront costs of buying a Moonlight and makes it more accessible), while those with higher purchasing power (individuals or companies) can buy somewhat more expensive systems.

Still, there needs to be funding for poor people to be able to get access to energy either via an arrangement like this or another type of (external) support, with a clear role for governments, international organizations, NGOs, corporate philanthropy or social venture capital. Or, as in the case of Grameen Shakti, a reliance on micro-finance 'soft credit' schemes for instalment payments for solar home systems that is offered via its relationship with the Grameen Bank. Sunlabob and Kamworks developed rental schemes in conjunction with micro-finance institutions and donors. Funding is also necessary for covering upfront investment and operating costs because it is relatively expensive to set up and maintain a stable system of electricity provision in remote rural areas - those locations where the true challenge of 'sustainable energy for all' lies. In many places, the situation is comparable to Cambodia and Laos, with similar issues as those faced by respectively Kamworks and Sunlabob. Until the moment that local, village-based systems can be connected to a regional or national grid in collaboration with a domestic utility, costly models will have to be set up and kept running. Even then, however, the problem may remain that (remote) rural consumers pay a higher price for electricity than those in traditionally grid-connected urban areas, which is likely to raise questions about equity (at the national level) at some point.

There may be locations where cheaper solutions are available, as the Indian case with electricity generation from discarded husk rice shows. Even there, however, funding for pilots and the start and set-up of the whole system is needed, requiring donors and/or socially-oriented investors with a longer-term orientation. With declining (relative) costs of renewable energy (see, for example, the price development of solar panels), possibilities to undertake more activities for less funding might increase, depending on local weather and geographical conditions, but a long-run commitment to a specific approach is necessary given the complexities of operating and building networks of suppliers. These types of support often run counter to donor approaches of funding for larger-scale one-off projects, 
competitive 'bidding' for grants, or shifting from one location/partner to another to cover multiple countries, satisfy diverse constituencies or jump on the bandwagon of a successful venture elsewhere.

There is also the issue, raised by interviewees, that 'theoretically' the role of the private sector is widely accepted, also by international (development) organizations, but that an understanding of the practical side of how business operates and what it requires to realise a profitable approach is something different. It is, for example in the case of sustainable energy, relatively easy to underline the importance of the "right" business models, but the road to building and then supporting such bottom-up entrepreneurial activity to sufficient scale is complex and protracted. Large, stand-alone donor programmes can distort local markets if they do not relate to local companies that need to play a role in longer-term solutions - especially in the case of rural electrification, small-scale rather than large business (let alone multinationals) will be actively involved.

These are concerns that are worthwhile to consider in shaping the (future) involvement of companies in establishing long-term sustainable markets in combination with support from governments and donor organizations, where applicable. Some issues, such as renewable, rural off-grid electrification, may need a form of collaboration by public, private and non-profit actors who subscribe to trajectories that become economically viable in the longer run or that rely on mixed forms of funding or partnership arrangements. The specifics may differ depending on local circumstances, as some business models seem to have the potential for economic viability, provided that there is sustained commitment based on indepth, local knowledge of markets, consumers and products/services. Further in-depth research on the peculiarities and dynamics would be very useful.

Related to the difficulties and limitations of collecting information about local companies active in remote rural settings, our article contained only a relatively small number of illustrative cases. While we covered a variety of technologies and approaches, embedded in a thorough examination of the available literature, follow-up studies that include more companies and from other countries would be helpful to shed more light on the topic. For the selection of a sample it should be noted, however, that small entrepreneurial ventures tend to be little formalized and often rather locally-oriented, and may thus be less or not visible on the internet, especially if they operate in poor regions where access is limited. This means that only those (larger ones) that already have international connections may show up through a web-based search. A second point is that many initiatives in, for example, sustainable energy, appear to be (predominantly) run by NGOs or supported by donors to such an extent that one cannot really speak of a privatesector activity.

Finally, although sustainable energy is a crucial lever for development, research on other important social and/or environmental issues could generate additional insight, also to extend our initial exploration in relation to the business model literature. Despite a growing interest in business models, academic publications hardly reckon with the specificities of developing countries, as we indicated in our article. As an initial contribution, we discussed our findings against a generic framework that we deemed most appropriate for the purpose, but this is something that deserves further careful attention as well. 


\section{NOTES}

${ }^{1}$ http://www.sustainableenergyforall.org/about-us.

${ }^{2}$ For recent insights into the broader micro-finance debate that often rely on empirical results from randomized controlled field experiments in the framework of MIT's Poverty Action Lab, see Banerjee and Duflo (2010), Chu (2007) and Karlan and Murdoch (2010). For several short practice-oriented articles on micro-finance, see e.g. Stanford Social Innovation Review, particularly in the 2007 and 2008 volumes.

${ }^{3}$ See a special issue with 19 articles on business models in Long Range Planning, Vol. 43 (2010), which included an introductory reflective piece by Baden-Fuller and Morgan (2010); and Zott et al.'s overview as published in the 2011 annual review issue of Journal of Management. 


\section{REFERENCES}

ARE (2008), Best Practices of ARE: What Renewable Energy Can Achieve in Developing Countries, Alliance for Rural Electrification, Brussels.

Baden-Fuller, C. and Morgan, M. S. (2010), "Business models as models", Long Range Planning, Vol. 43, pp. 156-171.

Banerjee, A. V. and Duflo, E. (2010), "Giving credit where it is due", Journal of Economic Perspectives, Vol. 24 No. 3, pp. 61-80.

Biswas, W., Bryce, P. and Diesendorf, M. (2001), "Photovoltaic technologies for poverty alleviation in rural Bangladesh", Environmental Science and Policy, Vol. 4, pp. 333-344.

Byrne, J., Shen, B. and Wallace, W. (1998), "The economics of sustainable energy for rural development: A study of renewable energy in rural China", Energy Policy, Vol. 26 No. 1, pp. 45-54.

Chakrabarti, A. and Chakrabarti, A. (2002), "Rural electrification programme with solar energy in remote region - case study in an island", Energy Policy, Vol. 30, pp. 33-42.

Chesbrough, H., Ahern, S., Finn, M. and Guerraz, S. (2006), "Business models for technology in the developing world: The role of non-governmental organizations", California Management Review, Vol. 48 No. 3, pp. 48-61.

Chu, M. (2007), "Commercial returns at the Base of the Pyramid", Innovations, Vol. 2 Nos. 12, pp. 115-146.

Dahan, N. M., Doh, J. P., Oetzel, J. and Yaziji, M. (2010), “Corporate-NGO collaboration: Cocreating new business models for developing markets", Long Range Planning, Vol. 43, pp. 326-342.

Davis, M. (1998), "Rural household energy consumption: The effects of access to electricityevidence from South Africa”, Energy Policy, Vol. 26 No. 3, pp. 207-217.

Eyring, M. J., Johnson, M. W., and Nair, H. (2011), "New business models in emerging markets", Harvard Business Review, Vol. 89 Nos. 1-2, pp. 89-95.

Fortanier, F. and Kolk. A. (2007), "On the economic dimensions of CSR: Exploring Fortune Global 250 reports", Business and Society, Vol. 46 No. 4, pp. 457-478.

Garrette, B. and Karnani, A. (2010), "Challenges in marketing socially useful goods to the Poor", California Management Review, Vol. 52 No. 4, pp. 29-47.

IEA (2006), World Energy Outlook 2010, OECD/IEA, Paris.

Ireland, J. (2008), "Lessons for successful BOP marketing from Caracas' slums", Journal of Consumer Marketing, Vol. 25 No. 7, pp. 430-438.

Jacobson, A. (2007), "Connective power: Solar electrification and social change in Kenya", World Development, Vol. 35 No. 1, pp. 144-162.

Karlan, D. and J. Morduch (2010), "Access to finance", in Rodrik, D. and Rosenzweig, M. (Eds.), Handbook of Development Economics, Elsevier, North-Holland, Vol. 5, pp. 47034784.

Kolk, A. and Pinkse J. (2010a), Policy Modes for Climate Change: The Role of Tripartite Partnerships, Partnerships Resource Centre, Working Paper 003, May.

Kolk, A. and Pinkse J. (2010b), The Climate Change -Development Nexus and Tripartite Partnerships, Partnerships Resource Centre, Working Paper 006, December.

Kolk, A., Rivera-Santos, M. and Rufín, C. (2010), "What do we really know about the Base of the Pyramid? A review and research agenda", paper presented at the Academy of Management Annual Conference, Montreal (August 6-10).

Kolk, A., Van Tulder, R. and Kostwinder, E. (2008), "Partnerships for development", European Management Journal, Vol. 26 No. 4, pp. 262-273. 
Kolk, A., Van Tulder, R. and Westdijk, B. (2006), "Poverty alleviation as business strategy? Evaluating commitments of frontrunner multinational corporations", World Development, Vol. 34 No. 5, pp. 789-801.

Ling, S., Twiddell, J. and Boardman, B. (2002), "Household photovoltaic market in Eining, Qinghai province, China: The role of local PV business", Solar Energy, Vol. 4, pp. 227240.

Martinot, E. (2001), "Renewable energy investments by the World Bank", Energy Policy, Vol. 29, pp. 689-699.

Meyer, K. E. (2004), "Perspectives on multinational enterprises in emerging economies", Journal of International Business Studies, Vol. 35, pp. 259-276.

Miller, D. and Hope, C. (2000), "Learning to lend off-grid solar power: Policy lessons from World Bank loans to India, Indonesia, and Sri Lanka", Energy Policy, Vol. 28, pp. 87-105.

Mohiuddin, S. (2006), "Expanding the role of microfinance in promoting renewable energy access in developing countries", The Georgetown Public Policy Review, Vol. 11 No. 1, pp. 119-124.

Morris, M., Schindehutte, M. and Allen, J. (2005), “The entrepreneur's business model: Toward a unified perspective", Journal of Business Research, Vol. 58, pp. 726-735.

Nguyen, K. (2007), "Alternatives to grid extension for rural electrification: Decentralized renewable energy technologies in Vietnam", Energy Policy, Vol. 35, pp. 2579-2589.

Nygaard, I. (2009), "The compatibility of rural electrification and promotion of low-carbon technologies in developing countries - The case of solar PV for Sub-Saharan Africa", European Review of Energy Markets, Vol. 3 No. 2, pp. 1-34.

O'Brien, G., O'Keefe, P. and Rose, J. (2007), "Energy, poverty and governance", International Journal of Environmental Studies, Vol. 64 No. 5, pp. 605-616.

Pitta, D. A., Guesalaga, R. and Marshall, P. (2008), "The quest for the fortune at the Bottom of the Pyramid: Potential and challenges", Journal of Consumer Marketing, Vol. 25 No. 7, pp. 393-401.

Prahalad, C. K. and Hart, S. (1999), "Strategies for the Bottom of the Pyramid: Creating sustainable development", Ann Arbor and Chapel Hill.

Rao, P., Miller, J., Wang, Y. and Byrne, J. (2009), "Energy-microfinance intervention for below poverty line households in India”, Energy Policy, Vol. 37, pp. 1694-1712.

REN21 (2010), Renewables: Global Status Report 2010, Paris.

Sagar, A. (2005), "Alleviating energy poverty for the world's poor", Energy Policy, Vol. 33, pp. 1367-1372.

Shafer, S. M., Smith, H. J., and Linder, J. C. (2005), "The power of business models", Business Horizons, Vol. 48, pp. 199-207.

Sharma, D. (2007), "Transforming rural lives through decentralized green power", Futures, Vol. 39, pp. 583-569.

Simanis, E. and Hart, S. (2008), "The Base of the Pyramid protocol: Toward next generation BoP strategy," Second edition, Center for Global Sustainable Enterprise, Cornell University.

Spalding-Fecher, R. (2005), "Health benefits of electrification in developing countries: A quantitative assessment in South Africa", Energy for Sustainable Development, Vol. 9 No. 1, pp. 53-62.

Spalding-Fecher, R., Winkler, H. and Mwakasonda, S. (2005), "Energy and the World Summit on Sustainable Development: What next?", Energy Policy, Vol. 33, pp. 99-112.

Umree, T. and Harries, D. (2006), "Renewable energy based rural electrification programs in developing countries: Lessons and perspectives", Sustainable Energy and Environment 


\section{Conference Proceedings.}

Umree, T., Harries, D. and Schlapfer, A. (2008), "A survey of the views of program implementers on success factors of solar PV programs in Asia and the Pacific", Ecocity World Summit 2008 Proceedings.

Umree, T., Harries, D. and Schlapfer, A. (2009), "Issues related to rural electrification using renewable energy in developing countries of Asia and Pacific", Renewable Energy, Vol. 34, pp. 354-357.

UN (2012). Sustainable Energy for All. A Framework for Action. The Secretary-General's High-Level Group on Sustainable Energy for All. Available at: $<$ http://www.un.org/wcm/webdav/site/sustainableenergyforall/shared/Documents/SE \%20for\%20All\%20-\%20Framework\%20for\%20Action\%20FINAL.pdf>

Van den Buuse, D., Kolk, A. and Pinkse, J. (2012). Access to Sustainable Energy in Emerging and Development Countries. Exploring Multi-Stakeholder Partnerships and Emerging Business Models on an International-to-Local Scale. Report for the Partnerships Resource Centre, 16 January.

Viswanathan, M., Seth, A., Gau, R., and Chaturvedi, A. (2009), "Ingraining product-relevant social good into business processes in subsistence marketplaces: The sustainable market orientation", Journal of Macromarketing, Vol. 29 No. 4, pp. 406-425.

Viswanathan, M. and Sridharans, S. (2009), "From subsistence marketplaces to sustainable marketplaces: A bottom-up perspective on the role of business poverty alleviation", Ivey Business Journal, Vol. 73 No. 2 (accessed September 6, 2010), [available at http://www.iveybusinessjournal.com/article.asp?intArticle_ID=816].

Wamukonya, N. and Davis, M. (2001), "Socio-economic impacts of rural electrification in Namibia: Comparisons between grid, solar and un-electrified households", Energy for Sustainable Development, Vol. 5 No. 3, pp. 5-13.

World Bank (2008a), Designing Sustainable Off-Grid Rural Electrification Projects: Principles and Practices, Washington D.C.

World Bank (2008b), The Welfare Impact of Rural Electrification: A Reassessment of the Costs and Benefits, Washington D.C.

Yunus, M., Moingeon, B. and Lehmann-Ortega, L. (2010), "Building social business models: Lessons from the Grameen experience", Long Range Planning, Vol. 43, pp. 308-325.

Zerriffi, H. (2011), Rural Electrification: Strategies for Distributed Generation, Springer, London.

Zott, C., Amit, R. and Massa, L. (2011), "The business model: Recent developments and future research", Journal of Management, Vol. 37, pp. 1019-1042. 


\section{FIGURES AND TABLES}

Figure 1. Indicative positioning of some off-grid delivery and financing models

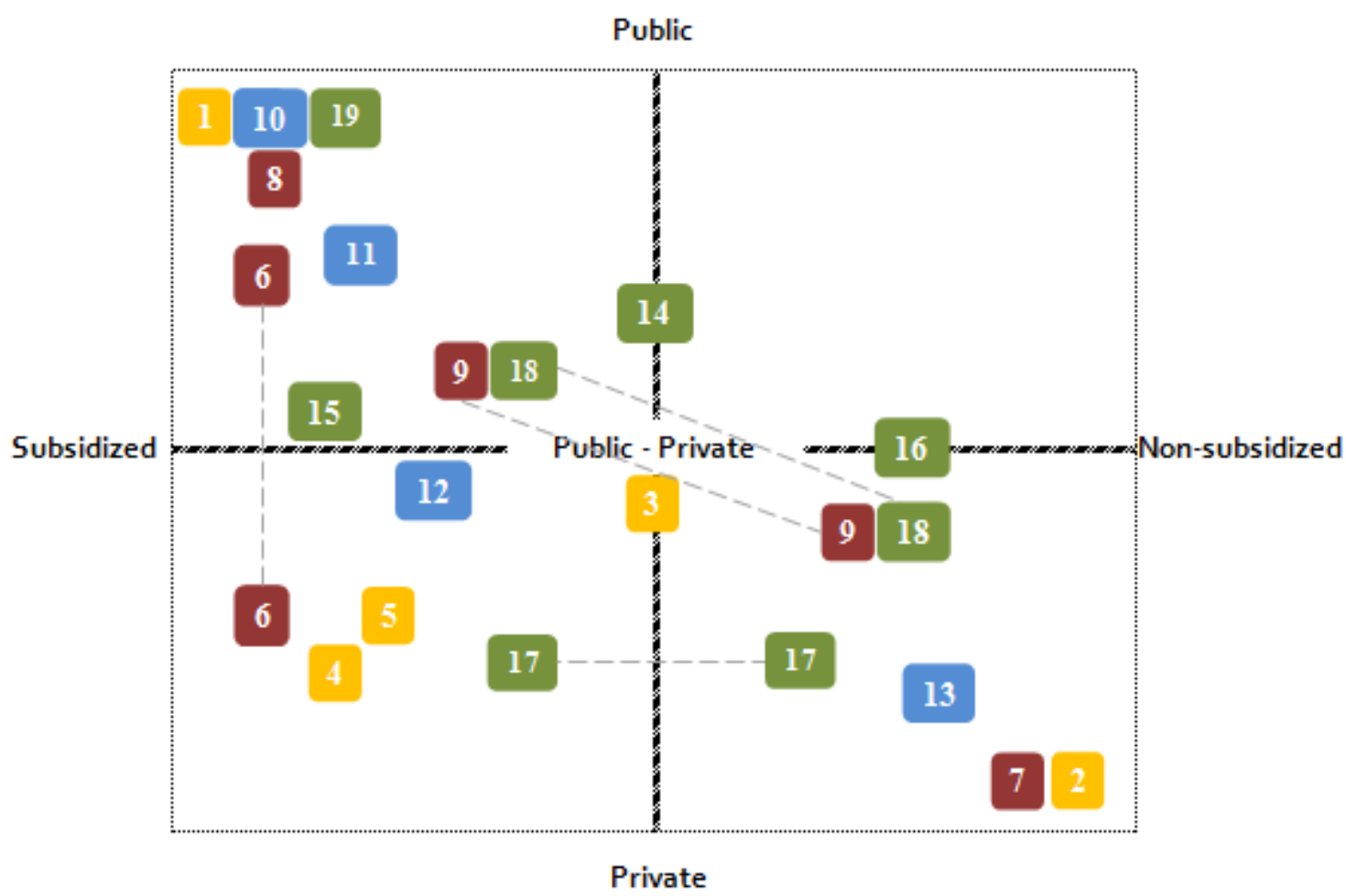

Nygaard (2009)

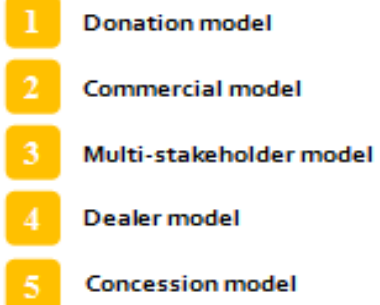

Umree and Harries (2006)

6 Fee-for service mode

7 Cash sales

8 Direct subsidies

9 Customer credit sales
Zerriffi (2011)

10 Government/donation model

11 Utility model

12 Mixed model

13 Decentralized model

Alliance of Rural Electrification (2008)

14 Regulated Purchase Tariff

15 Connection-based subsidy

16 Clean Development Mechanism

17 Power Purchase Agreement

18 Micro-financing

19 Donations 
Box 1. Renewable Energy Technologies (RETs) for developing countries

A broad range of RET-based applications for decentralized off-grid electrification including solar, wind, hydro and hybrid systems has become available in recent years. For the main applications in domestic use, such as lighting and usage of electrical appliances (e.g. television, radio, mobile phones), REN21 (2010) states that the main options include the following: solar home systems (SHS) applied to individual homes, schools or hospitals; village-scale mini-grids powered by solar, wind or hybrid technologies; small-scale biomass gasifiers with gas engines; and hydropower installations on a pico-scale, micro-scale or small-scale. In addition to utilizing solar energy through SHS, ARE (2008) also mentions two options for solar photovoltaic (PV) which create high flexibility in usage as they are easy to move and share: small solar PV applications, consisting of solar PV modules attached to a specific application, and energy boxes, consisting of a portable loading station with power outlets for creating a connection to specific applications.

When considering appropriate RETs for electrification in developing countries, it is important to define dimensions on which the choice for a specific energy system can be made, as a broad spectrum of stand-alone and mini-grid based RET applications has emerged in recent years. Selecting the best technological configuration for rural electrification from the diverse range of available options mentioned above should be done on a case-to-case basis, as the specific conditions in a geographical area determine the most effective technology solution (ARE, 2008). O'Brien et al. (2007) identify several general characteristics for selecting the appropriate RET-based solution for electrification, including the efficiency, adaptability, reparability, and ease of use of the technology, which are rather context-specific and dependent on the needs of the end-consumer. Reliability and affordability are also often mentioned as crucial aspects (e.g. Umree and Harris, 2006).

Table 1. Six questions that underlie a business model

\begin{tabular}{|l|l|}
\hline Question & \multicolumn{1}{|c|}{ Some subcomponents } \\
\hline How will the firm create value? & - Peculiarities of the offering \\
\hline $\begin{array}{l}\text { For whom will the firm create } \\
\text { value? }\end{array}$ & $\begin{array}{l}\text { - Market factors such as business-to-business or business-to-consumer, local- } \\
\text { international, value-chain position of customer, market segments }\end{array}$ \\
\hline $\begin{array}{l}\text { What is the firm's internal source } \\
\text { of competitive advantage? }\end{array}$ & $\begin{array}{l}\text { - Internal capability factors including production, sales, technology, finance, } \\
\text { supply chain management, leveraging of networks and resources }\end{array}$ \\
\hline $\begin{array}{l}\text { How will the firm position itself in } \\
\text { the marketplace? }\end{array}$ & $\begin{array}{l}\text { - Competitive strategy factors such as operational excellence, product/service } \\
\text { quality, innovation/cost leadership, customer relationship/experience }\end{array}$ \\
\hline How will the firm make money? & $\begin{array}{l}\text { - Economic factors such as pricing and revenue sources, operating leverage, } \\
\text { volumes and margins }\end{array}$ \\
\hline $\begin{array}{l}\text { What are the entrepreneur's time, } \\
\text { scope, and size ambitions? }\end{array}$ & \begin{tabular}{l} 
Type of investment model (e.g. subsistence, income, growth, speculation) \\
\hline
\end{tabular} \\
\hline
\end{tabular}

Source: Taken from Morris et al. (2005, pp. 729-730). 
Table 2. Some characteristics of the four local companies included in this article

\begin{tabular}{|c|c|c|c|c|}
\hline & Grameen Shakti (GS) & Husk Power Systems (HSP) & Kamworks & Sunlabob \\
\hline Year of creation & 1996 & 2008 & 2006 & 2000 \\
\hline Country of origin & Bangladesh & India & Cambodia & Laos \\
\hline $\begin{array}{l}\text { Countries/(sub) } \\
\text { regions of activity }\end{array}$ & Main market is Bangladesh & Main market is India's Bihar state & Main market is Cambodia & $\begin{array}{l}\text { Main market is Laos, also international activities } \\
\text { on project basis in Thailand, Cambodia, Uganda, } \\
\text { Sierra Leone, Mozambique, Liberia, and } \\
\text { Afghanistan (some starting from } 2012 \text { onwards) }\end{array}$ \\
\hline $\begin{array}{l}\text { Main products } \\
\text { /technologies (cf. } \\
\text { Box 1) }\end{array}$ & $\begin{array}{c}\text { Solar home systems, improved cooking stoves, } \\
\text { biogas plants. All include a programme } \\
\text { incorporating credit schemes and microfinance } \\
\text { options }\end{array}$ & $\begin{array}{l}\text { Biomass gasifier running on rice husk, } \\
\text { distributed by village grid }\end{array}$ & $\begin{array}{l}\text { Grid-connected and off-grid solar systems, } \\
\text { water systems (pump), solar home systems } \\
\text { (sizes 20W to } 320 \mathrm{~W}) \text {, Moonlight solar } \\
\text { lantern, solar-powered cooling }\end{array}$ & $\begin{array}{l}\text { Grid-connected solar systems, village grid systems } \\
\text { (technologies: hybrid, solar, hydro, wind), solar } \\
\text { home systems (sizes } 20 W \text { to } 150 \mathrm{~W} \text { ), solar } \\
\text { lanterns, water systems (pump, purification, } \\
\text { treatment, heater), solar-powered cooling } \\
\end{array}$ \\
\hline Main services & $\begin{array}{l}\text { Installation and maintenance, awareness } \\
\text { raising and demonstration, training programs. } \\
\text { Entrepreneur development through Grameen } \\
\text { Technology Centres, credit schemes }\end{array}$ & $\begin{array}{l}\text { Installation and maintenance, training } \\
\text { programs through Husk Power University }\end{array}$ & $\begin{array}{l}\text { Installation and maintenance, awareness } \\
\text { raising and demonstration, rental scheme on } \\
\text { solar lantern }\end{array}$ & $\begin{array}{l}\text { Installation and maintenance, consultancy on } \\
\text { electrification and energy efficiency, project } \\
\text { management, training programs, awareness } \\
\text { raising and demonstration, rental schemes on } \\
\text { energy systems and solar lanterns } \\
\end{array}$ \\
\hline Types of customers & $\begin{array}{l}\text { b-to-c, predominantly low-income customers in } \\
\text { rural Bangladesh }\end{array}$ & $\begin{array}{l}\text { b-to-c, predominantly low-income customers } \\
\text { in rural India }\end{array}$ & $\begin{array}{l}\text { B-to-b and b-to-c, broad customer base from } \\
\text { organizations/business to middle- and low- } \\
\text { income customers in rural Cambodia }\end{array}$ & $\begin{array}{l}\text { B-to-b and b-to-c, broad customer base from } \\
\text { organizations/business to middle- and low- } \\
\text { income customers in rural/urban Laos }\end{array}$ \\
\hline $\begin{array}{l}\text { Key achievements / } \\
\text { statements }\end{array}$ & $\begin{array}{l}\text { (1) "Grameen Shakti has developed one of the } \\
\text { most successful market based programs with a } \\
\text { social objective for popularizing Solar Home } \\
\text { Systems (SHSs) including other renewable } \\
\text { energy technologies to millions of rural } \\
\text { villagers" } \\
\text { (2) Since its inception, Grameen Shakti } \\
\text { achieved a total of } 815,528 \text { of installed Solar } \\
\text { Home Systems, a total of } 463,842 \text { distributed } \\
\text { ICS, and a total of } 22.096 \text { installed Biogas } \\
\text { Plants. It has } 1217 \text { branch offices throughout all } \\
64 \text { districts in Bangladesh, with a total of } 1445 \\
\text { offices including regional and divisional offices, } \\
\text { with a total of around } 5 \text { million beneficiaries } \\
\text { (figures for May 2012). } \\
\text { (3) "GS used its Grameen Bank's experience to } \\
\text { evolve a financial package based of installment } \\
\text { payment which reduced costs and helped it } \\
\text { reach economy of scale" }\end{array}$ & $\begin{array}{l}\text { (1) "The company designs, installs and } \\
\text { operates biomass-based power plants. Each } \\
\text { plant uses proprietary gasification technology } \\
\text { to convert abundant agricultural residue } \\
\text { (procured from local farmers) into electricity, } \\
\text { which is then distributed to rural households } \\
\text { and micro-enterprises through a micro-grid } \\
\text { system - providing a better quality, } \\
\text { cheaper way to meet their need for energy" } \\
\text { (2) "Consumers pre-pay a fixed monthly fee } \\
\text { ranging from US\$2 to US\$2.50 to light up two } \\
\text { fluorescent lamps and one mobile charging } \\
\text { station. This offers consumers savings of at } \\
\text { least } 30 \% \text { over competing kerosene and } \\
\text { diesel energy sources" } \\
\text { (3) "Since } 2008, \text { HPS has successfully installed } \\
\text { more than } 80 \text { plants in Bihar, providing } \\
\text { electricity to over 200,000 people across } 300 \\
\text { villages" }\end{array}$ & $\begin{array}{l}\text { (1) "Kamworks tries to introduce the so- } \\
\text { called energy ladder: for the lowest income } \\
\text { household we have the Moonlight (a solar- } \\
\text { powered lantern), and for the medium and } \\
\text { higher income households we have a SHS } \\
\text { systems in } 20 \text { watt, } 40 \text { watt and } 80 \text { watt" } \\
\text { (2) "In the first place Kamworks sells and } \\
\text { installs solar electricity systems for } \\
\text { professional end-users that have a need for } \\
\text { electricity in the rural areas (high-end). In the } \\
\text { second place, the company imports, } \\
\text { develops, produces and sells products based } \\
\text { on solar electricity for the consumer market } \\
\text { (low end)" } \\
\text { (3) "International experience shows that the } \\
\text { biggest problems with battery operated solar } \\
\text { systems are usually related to the quality of } \\
\text { the product and lack of a functioning local } \\
\text { service network". }\end{array}$ & $\begin{array}{l}\text { (1) "Sunlabob operates as a profitable, full-service } \\
\text { renewable energy provider, providing } \\
\text { commercially-viable energy services" } \\
\text { (2) "Sunlabob believes that responsible, long- } \\
\text { term oriented entrepreneurship is the driving } \\
\text { force for sustainable economic development and } \\
\text { for providing managerial, technical, and financial } \\
\text { resources needed to meet social and } \\
\text { environmental challenges" } \\
\text { (3) "Sunlabob installed more than 10,000 systems } \\
\text { in over } 500 \text { villages and locations in Laos" } \\
\text { (4) "Sunlabob has successfully initiated a rental } \\
\text { service for energy systems and a Solar Lantern } \\
\text { Rental System that allows households and villages } \\
\text { to afford electricity" }\end{array}$ \\
\hline
\end{tabular}




\begin{tabular}{|c|c|c|c|c|}
\hline & Grameen Shakti (GS) & Husk Power Systems (HSP) & Kamworks & Sunlabob \\
\hline Awards & $\begin{array}{c}\text { Awards include: SolarWorld Einstein Award } \\
\text { (2010), International Microfinance Award } \\
\text { (2009), Ashden Outstanding Achievement } \\
\text { Award (2008), Energy Globe Award (2008), and } \\
\text { the Ashden Award (2006) }\end{array}$ & $\begin{array}{c}\text { Awards include: Ashden Award for } \\
\text { Sustainable Energy (2011), Africa Enterprise } \\
\text { Challenge Fund Award (2011), and Real } \\
\text { Heroes Award - Social Welfare for founder } \\
\text { Gynesh Pandey }\end{array}$ & $\begin{array}{c}\text { Awards include: Clean Energy Marketplace } \\
\text { Award by USAID, ADB, and RWI (2010), } \\
\text { Development Marketplace Award by the } \\
\text { World Bank (2006) }\end{array}$ & $\begin{array}{l}\text { Awards include: Development Marketplace } \\
\text { Award by the World Bank (2005), Ashden Award } \\
\text { for Sustainable Energy (2007), Energy Globe } \\
\text { Award - Laos (2007 / 2008 / 2009), Cleantech } \\
\text { National Competition in Singapore Award (2010), } \\
\text { and Best Practice in CSR Award (2012) }\end{array}$ \\
\hline Size & 10.341 employees ( 7 executive management) & 350 employees (6 executive management) & Not specified (estimated 15-25 employees) & Around 70 employees \\
\hline Subsidies obtained & $\begin{array}{c}\text { States to get ' } n \text { o direct subsidies', focus on } \\
\text { micro-credit financing in collaboration with } \\
\text { Grameen Bank (no mention of subsidies by this } \\
\text { company) }\end{array}$ & $\begin{array}{l}\text { Investments from a number of organizations } \\
\text { including international organizations, } \\
\text { foundations, venture capital firms, and non- } \\
\text { profit venture funds }\end{array}$ & $\begin{array}{c}\text { From international (development ) } \\
\text { organizations for supplying and installing } \\
\text { RET-based energy solutions on project-basis, } \\
\text { which includes the World Bank and Energy \& } \\
\text { Environmental Partnership Mekong }\end{array}$ & $\begin{array}{c}\text { From international (development) organizations } \\
\text { for supplying and installing RET-based energy } \\
\text { solutions on project-basis, which includes the } \\
\text { World Bank, Asian Development Bank, and United } \\
\text { Nations/UNIDO }\end{array}$ \\
\hline $\begin{array}{l}\text { Partnerships within } \\
\text { private sector }\end{array}$ & Not specified & $\begin{array}{c}\text { Investors include Shell Foundation, Draper } \\
\text { Fisher Jurvetson (DFJ), LGT Venture } \\
\text { Philanthropy, Bamboo Finance (Oasis } \\
\text { Capital), and Cisco }\end{array}$ & $\begin{array}{l}\text { Includes private sector partners for supply of } \\
\text { products (organizations not specified) }\end{array}$ & \begin{tabular}{|c|} 
Includes private sector partners for supply of \\
products ( 21 organizations), projects $\&$ \\
implementation (11 organizations), and business \\
strategy development ( 3 organizations)
\end{tabular} \\
\hline $\begin{array}{l}\text { Partnerships with } \\
\text { governmental } \\
\text { actors }\end{array}$ & Not specified & $\begin{array}{c}\text { Includes The Ministry of New and Renewable } \\
\text { Energy (MNRE), Govt. of India and World } \\
\text { Bank/IFC }\end{array}$ & $\begin{array}{l}\text { Includes Agentschap NL (Netherlands) and } \\
\text { GIZ (Germany) }\end{array}$ & $\begin{array}{l}\text { Includes United Nations/UNESCAP, World } \\
\text { Bank/IFC, GIZ (Germany), SES (Germany), Lao } \\
\text { Institute for Renewable Energy (LIRE) }\end{array}$ \\
\hline $\begin{array}{l}\text { Partnerships with } \\
\text { NGOs }\end{array}$ & Not specified & Includes the Acumen Fund & $\begin{array}{l}\text { Includes Energy \& Environmental Partnership } \\
\text { (EEP) Mekong, PicoSol Cambodia, } \\
\text { CICM/Crédit Mutuel Kampuchea, the Delft } \\
\text { University of Technology (Netherlands), the } \\
\text { University Twente (Netherlands), and Kofi } \\
\text { Annan Business School (Netherlands) }\end{array}$ & $\begin{array}{c}\text { Includes The Asia Foundation, Engineers Without } \\
\text { Borders Australia, FK Norway, Cambodia Rural } \\
\text { Development Team, World Volunteer }\end{array}$ \\
\hline $\begin{array}{l}\text { Most applicable } \\
\text { model(s) ( Figure 1) }\end{array}$ & $\# 9, \# 18$ & $\# 2, \# 7, \# 13$ & $\# 2, \# 7, \# 13$ & $\# 2, \# 5, \# 6, \# 13$ \\
\hline
\end{tabular}

Source: Company websites, reports and interviews 